\title{
Development of E-Module Based on Local Culture of North Sumatra in the Indonesian Language Skills and Literature Appreciation Elementary School Course
}

\author{
$1^{\text {st }}$ Faisal Faisal $^{1}, 2^{\text {nd }}$ Erlinda Simanungkalit ${ }^{2}, 3^{\text {rd }}$ Masta Marselina Sembiring $^{3}$ \\ \{faisalpendas@gmail.com ${ }^{1}$, erlinda@ unimed.ac.id ${ }^{2}$, masta.marselina88@gmail.com ${ }^{3}$ \} \\ Faculty of Education, Universitas Negeri Medan, Indonesia ${ }^{1,2,3}$
}

\begin{abstract}
This study aims to develop an E-Module Based on North Sumatran Local Culture in the Indonesian Language Skills and Literature Appreciation Elementary School course. This E-Module is one of the alternative teaching materials in the Merdeka Belajar Kampus Merdeka (MBKM) program at PGSD FIP UNIMED because it is directly integrated with the local culture of North Sumatra. Through this E-Modul, students from outside North Sumatra gain new knowledge and experiences related to local culture in North Sumatra. This research is a development research using a 4D model (Define, Design, Development, and Disseminate). The focus of the research is on 3 aspects, namely validity, practicality, and effectiveness of the developed E-Module. Data were collected using validation sheets (content validity and construct validity), lecturer and student response questionnaires (practical test), and student learning success test (effectiveness test). The research data were then analyzed quantitatively and qualitatively. The results showed that: (1) the validity of the E-Module was in the Very Valid category with an average score of 3.63; (2) Practicality of the E-Module is in the Very Practical category with an average score of 3.64; and (3) the effectiveness of the EModule is in the Effective category with a learning success rate $90 \%$. Based on these findings, it can be concluded that the E-Module has been declared valid, practical, and effectively used in the Indonesian Language Skills and Literature Appreciation Elementary School course.
\end{abstract}

Keywords: E-Module, MBKM, validity, practicality, effectiveness.

\section{Introduction}

Merdeka Belajar Kampus Merdeka (MBKM), is a policy of the Minister of Education, Culture, Research, and Technology that aims to encourage students to master various sciences that are useful for entering the world of work. Merdeka Campus provides an opportunity for students to choose the courses they will take. The MBKM policy states that the fulfillment of the study period and load for undergraduate or applied undergraduate students can be carried out [1]: (a) following the entire learning process in the study program at the university according to the study period and load; and (b) following the learning process in the study program to fulfill part of the time and learning load and the rest following the learning process outside the study program.

Through the MBKM program, students have the opportunity for 1 (one) semester or equivalent to 20 (twenty) credits to study outside the study program at the same university; 
and a maximum of 2 (two) semesters or equivalent to 40 (forty) credits of studying in the same study program at different universities, learning in different study programs at different universities; and/or learning outside of Higher Education. Learning in the Merdeka Campus provides challenges and opportunities for the development of creativity, capacity, personality, and student needs, as well as developing independence in seeking and finding knowledge through realities and field dynamics such as ability requirements, real problems, social interaction, collaboration, self-management, performance demands. , targets and achievements.

Basically, the lecture process in higher education requires independent efforts from students. The lecture process like this distinguishes the learning patterns of students from students, the lecturer only acts as a mediator and facilitator [2]. This is in line with MBKM learning which encourages lecturers to play a full role as mediator and facilitator. To carry out their role effectively, lecturers should develop MBKM learning tools that are relevant to the needs of students. With the learning tools developed, students are expected to be able to take part in MBKM learning independently without having to face to face with the lecturer concerned.

One of the important elements of the MBKM learning tool is the learning module. Lecturers are expected to be able to process and design learning modules that are interactive, digital-based, and integrated with local culture. Through this module, in addition to students being able to learn independently from anywhere and anytime, it will also present and provide new experiences for students, especially those related to the local culture of the local area. The importance of developing electronic modules in learning. Electronic modules can display text, images, animations, and videos through electronic devices such as computers [3]. In addition, this electronic module can be used as an alternative to efficient and effective learning, as well as interactive. The existence of the electronic module is expected to be one of the new learning resources for students which is then expected to improve understanding of concepts and learning outcomes in MBKM.

In addition, in addition to lecturers being given the freedom to develop modules electronically, lecturers must also be able to design and determine their own learning modules that are in accordance with the cultural model in which they teach. This flexibility must be seen from the side of module development which is based on the objectives that have been outlined. Thus, the development of learning modules is given to lecturers in full by prioritizing the principles of the objectives to be achieved. Because of the flexibility given, lecturers must be creative in designing modules that promote local culture in the environment where students are [4].

In response to the explanation above, each course that participates in MBKM learning should be able to develop students' creativity, capacity, personality, and needs, as well as develop independence in seeking and finding knowledge through realities and field dynamics. In addition, the courses developed must also have their own uniqueness and characteristics in accordance with the characteristics of local universities. This is important so that the selected and prioritized courses in MBKM can provide new knowledge and provide different experiences, especially for students who come from outside the university.

Based on the author's initial reflection for the even semester of the 2020/2021 academic year related to the readiness of the learning module for the MBKM subject in the Primary School Teacher Education Study Program, Faculty of Education, State University of Medan, especially the Language Skills and Appreciation of Indonesian Literature courses in Elementary Schools has not been able to accommodate the needs MBKM learning as previously stated. The current learning module is still print-based and not yet interactive. This 
has an impact on the difficulty of students from outside the State University of Medan to access this module due to distance constraints and lack of facilitating students to study independently. In addition, students cannot find relevant examples of modules digitally because they are not equipped with images, animations, and videos that are provided electronically. Meanwhile, the current online learning pattern is in dire need of relevant examples in the form of images, animations, and videos that can be accessed digitally.

Another thing that becomes the main problem in this course module is that it does not yet have its own characteristics and characteristics that are worthy of being introduced as MBKM courses. The material presented in this course module is still general in nature which almost has the same study as other universities in Indonesia. Ideally, MKBM courses should be able to present something different so as to provide new knowledge and different experiences for students, especially those from outside the State University of Medan. In short, this course does not yet have a selling point as an MBKM elective course for students from outside the Medan State University campus which presents material according to the local culture in North Sumatra.

In response to the above problems, it is necessary to develop a digital-based, interactive, and integrated learning module for the Indonesian Language Skills and Literature Appreciation Course for Elementary Schools in North Sumatra. With the development carried out, students are expected to be able to learn anytime and from anywhere according to the characteristics of MBKM learning. In addition, students are expected to be able to learn independently because the modules developed are interactive by presenting them as if the lecturers interacted directly with students. This is certainly very supportive for distance learning / online learning today. What is no less important is that this course has its own selling point and attractiveness because it presents material that is directly integrated with the local culture in North Sumatra. By presenting this material, students from outside the Medan State University campus will gain new knowledge and new experiences, especially those related to the local culture of North Sumatra.

\section{Method}

This type of research is research and development (Research and Development). The development model used in this study is the 4-D development model (four D models). The stages of the 4-D model include: defining, designing, developing, and disseminating [5]. The development research procedure carried out contains the steps that must be carried out as shown in Figure 1 below. 


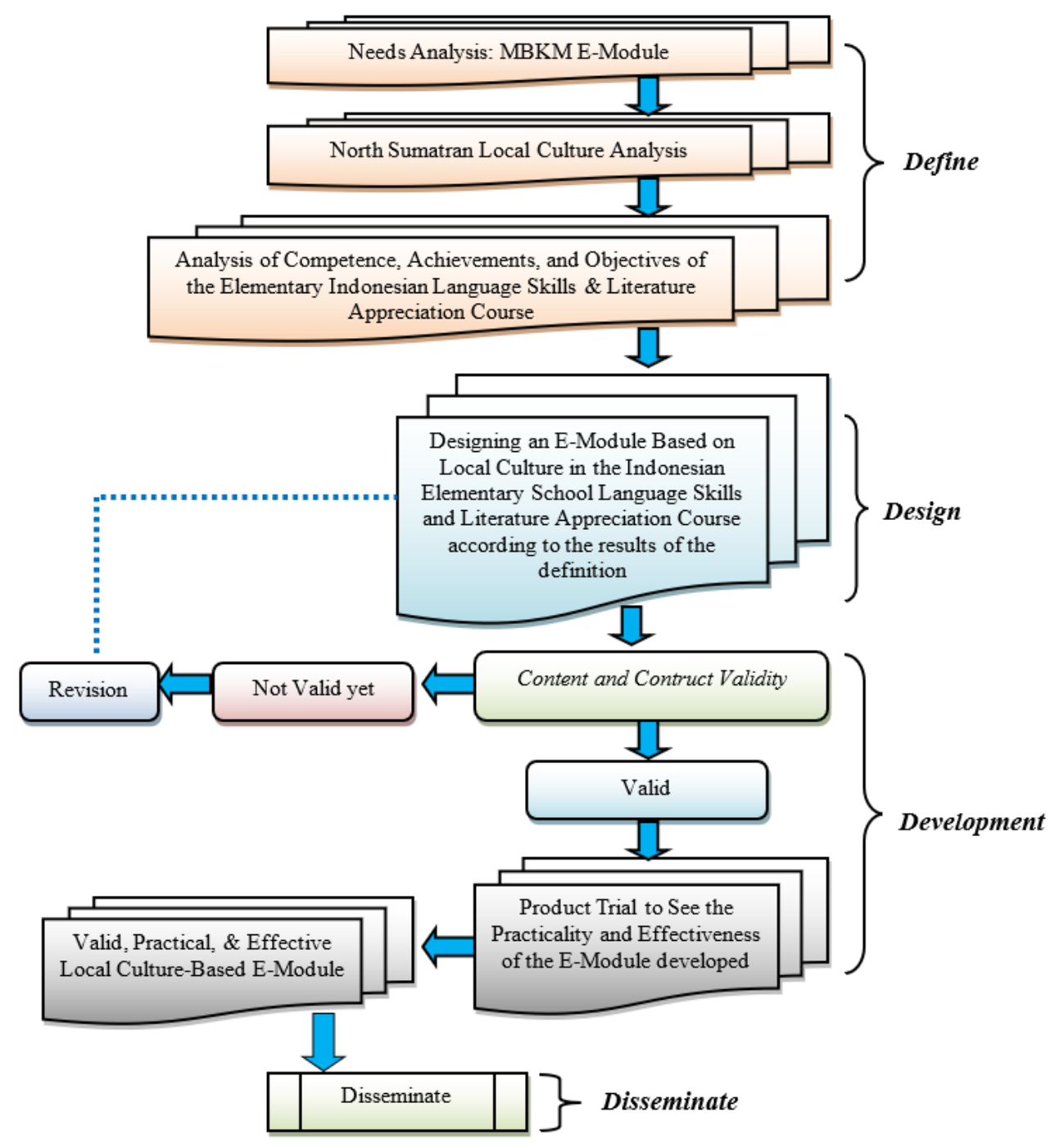

Fig. 1. Local Culture-Based E-Module Development Procedure.

The stages of development in Figure 1 can be detailed as follows:

a. The definition stage aims to define and analyze the following: (a) needs analysis, namely what kind of E-Module is currently needed in the MBKM program, (b) task analysis, namely determining attitudes, knowledge, and student skills, (c) analysis of the local culture of North Sumatra which is integrated into the E-Module, and (d) analysis of competence (Direct Learning Outcomes of Study Programs and Course Learning Outcomes).

b. The design stage is to design the E-Module according to the definition: needs analysis, task analysis, local culture analysis, and competency analysis.

c. The development phase includes: validity test, practicality test, and effectiveness test. 
d. The dissemination stage is carried out on a wider scale, both in other classes in the Elementary School Teacher Education Study Program, Faculty of Education, State University of Medan and at other universities.

\section{Results and Discussion}

\subsection{Results}

Validity of E-Module. The results of the analysis of the level of validity of the developed emodule can be seen in Table 1 below.

Table 1. Results of Validation of Teaching Materials by Expert Validators.

\begin{tabular}{clcc}
\hline No & Rated Aspect & Validation Value & Category \\
\hline 1. & Content Feasibility & 3.72 & Very Valid \\
2. & Linguistic & 3.60 & Very Valid \\
3. & Presentation & 3.62 & Very Valid \\
4. & Grafting & 3.57 & Valid \\
\hline & Average & $\mathbf{3 . 6 3}$ & Very Valid \\
\hline
\end{tabular}

Based on the data in Table 1, it can be explained that the validation value from the content feasibility aspect is at 3.72 with a very valid category, the validation value from the linguistic aspect is at 3.60 with a very valid category, the validation value from the presentation aspect is at 3.62 with a very valid category, and the validation value from the graphic aspect is at 3.57 with a valid category. Based on this data, the average validation value of the developed emodule is 3.63 with a very valid category.

Practicality of E-Module. The practicality referred to in this case is the level of convenience of students in using the developed e-module. To see the level of convenience of students in using the e-module, several questions were asked related to the following aspects: (a) do students easily understand the various concepts contained in the e-module?; (b) is it easy for students to understand the steps of the activities in the e-module?; (c) are students interested and motivated to learn from the e-module design displayed?; and (d) are students active and enthusiastic about doing the tasks in the e-module?

In the first aspect, the research findings show that MBKM students are very easy to understand the various concepts in the developed e-module (average 3.64). The ease of understanding this concept occurs because it is supported by authentic examples and best practices that are presented digitally in the form of images or interactive videos. In this case, very minimal misconceptions occur from each concept described. In the second aspect, it was found that it was very easy for students to understand the activity steps in the e-module because it was presented interactively and with relevant examples (average 3.63). In the third aspect, it was found that students were very interested and motivated to learn because the emodule developed was designed with a choice of colors, layouts, and combinations of images/videos in accordance with the local culture in North Sumatra (average 3.66). In the fourth aspect, it was found that students were active and enthusiastic in doing the tasks in the 
e-module (average 3.63). This can be seen from the active participation of students and the quality of the student worksheets collected.

Based on the results of the research at the practical level, it was found that the e-module developed was very practical to use in learning the Indonesian Elementary School Language Skills and Literature Appreciation course (average 3.64). This means that the e-module developed is very easy for students to use in online learning and highly motivates students to study, both independently and in groups.

Effectiveness of E-Module. The research findings related to the effectiveness of the developed e-module are seen based on 2 analyzed aspects, namely: (a) student activities and (b) learning success.

First, an overview of student activity levels can be seen in Table 2 below.

Table 2. Results of Observation of Student Activities.

\begin{tabular}{|c|c|c|c|}
\hline No & Aspects Observed & Percentage (\%) & Category \\
\hline 1. & $\begin{array}{l}\text { Paying attention and listening to the } \\
\text { lecturer's explanation }\end{array}$ & 91.67 & Very Good \\
\hline 2. & Pay attention to teaching materials & 77.08 & Good \\
\hline 3. & $\begin{array}{l}\text { Carry out the steps of the activities } \\
\text { contained in the teaching materials }\end{array}$ & 89.58 & Very Good \\
\hline $\begin{array}{l}4 . \\
5 .\end{array}$ & $\begin{array}{l}\text { Asking question } \\
\text { Respond }\end{array}$ & $\begin{array}{l}83.33 \\
66.67\end{array}$ & $\begin{array}{l}\text { Very Good } \\
\text { Good }\end{array}$ \\
\hline & Average & 81.57 & Very Good \\
\hline
\end{tabular}

Table 2 above illustrates that student activities when the learning process takes place are obtained an average of $81.57 \%$ with a very good category. It can be said that students are enthusiastic when participating in the learning process through the developed e-module. For more details, see the following description.

Students pay attention and listen well when the lecturer explains the lecture material on the e-module. This can be seen from the average value obtained through the observation sheet, which is $91.67 \%$ with a very good category. Then, when doing lecture assignments, students pay close attention to the e-module. The average obtained based on observations in this aspect is $77.08 \%$ with a good category. The steps in the e-module are also well done. This can be seen in the average obtained from the observations, which is $89.58 \%$ with a very good category.

Furthermore, students can ask questions properly if there is material that is not understood in the e-module. The average value obtained from the observations is $83.33 \%$ with a very good category. However, the response aspect decreased slightly when compared to the previous aspect. However, the average obtained based on observations on the aspect of responding is $66.67 \%$ in the good category. This means that students can provide good responses, although less than other aspects.

Second, the level of effectiveness of learning success using e-module can be explained that the average classical completeness score reaches $90 \%$. That is, there are $90 \%$ of students who get a minimum score of B using the developed e-module. Based on this data, it can be concluded that the developed e-module is very effectively used as a learning resource for MBKM students in the Elementary School Teacher Education Study Program, Faculty of Education, State University of Medan. 


\subsection{Discussion}

Validity of E-Module. Referring to the results of previous studies, it is explained that the feasibility or level of validity of the development of learning tools is at least in the valid category [6]. The findings of the research show that the average level of validity of the emodule developed is at 3.63 with a very valid category. Based on this data, it can be concluded that the developed e-module is very suitable to be used as a source of student learning in attending the English Language Skills and Appreciation of Indonesian Literature Elementary School courses.

Practicality of E-Module. Referring to previous research, it was explained that the level of practicality of learning tools was at least in the practical category [7]. The research findings related to the practicality of the developed e-module are in the very practical category. This means that the e-module developed is very easy for students to use in learning the Indonesian Language Skills and Literature Appreciation Elementary School courses.

Effectiveness of E-Module. Referring to previous research, it was explained that the level of effectiveness of learning tools was at least in the good category and at least $75 \%$ classically complete [8]. When viewed from the activities of students attending lectures, they are in the very good category. Meanwhile, classical mastery of learning success obtained an average of $90 \%$. This means that the developed e-module is said to be very effective in teaching the Indonesian Language Skills and Literature Appreciation Elementary School course.

\section{Conclusion}

Based on the research findings, some conclusions can be drawn as follows: a) The average level of validity of the developed e-module is at 3.63 with a very valid category. that is, the e-module developed is very suitable to be used in learning MBKM for the Indonesian Language Skills and Literature Appreciation Elementary School course. b) The level of practicality of the developed e-module is in the very practical category. This means that the emodule developed is very easy for students to use in attending lectures on the Indonesian Language Skills and Literature Appreciation Elementary School course. c) The effectiveness level of the developed e-module is in the very effective category. This means that the emodule developed is very effective in increasing student activity and success in learning the Indonesian Elementary School Language Skills and Literature Appreciation course.

\section{References}

[1] Mendikbud RI. Peraturan Menteri Pendidikan dan Kebudayaan Republik Indonesia Nomor 3 Tahun 2020 Tentang Standar Nasional Pendidikan Tinggi. Indonesia: Menteri Pendidikan dan Kebudayaan RI; 2020. 1-76.

[2] Hartono W, Noto MS. Pengembangan Modul Berbasis Penemuan Terbimbing untuk Meningkatkan Kemampuan Matematis pada Perkuliahan Kalkulus Integral. JNPM (J Nas Pendidik Mat). 2017; 1(2):320-333 .

[3] Imansari N, Sunaryantiningsih I. Pengaruh Penggunaan E-Modul Interaktif terhadap Hasil Belajar Mahasiswa pada Materi Kesehatan dan Keselamatan Kerja. VOLT J Ilm Pendidik Tek Elektro. 2017; 2(1):11-16. 
[4] Ferdianto F, Setiyani S. Pengembangan Bahan Ajar Media Pembelajaran Berbasis Kearifan Lokal Mahasiswa Pendidikan Matematika. JNPM (Jurnal Nas Pendidik Mat). 2018; 2(1):37-47.

[5] Sugiyono. Metode Penelitian Pendidikan: Pendekatan Kuantitatif, Kualitatif, dan R\&D. $7^{\text {th }}$ Edition. Bandung: Alfabeta; 2009.

[6] Faisal F, Lova SM. The Development of Reading Learning Material Based on DRTA Strategy as an Effort to Build a Literate Generation in Fifth Grade (5th) of Primary School. Sch Educ J PGSD FIP Unimed. 2018; 8(2):145-158.

[7] Faisal ES, Lova SM. The Development Of E-Learning Instruments-Based For Bahasa Indonesia's Subject In Elementary School Education Undergraduate Program Of Universitas Negeri Medan. The 3rd International Conference Community Research and Service Engagements (IC2RSE); $4^{\text {th }}$ December 2019; North Sumatra. EAI; 2019.

[8] Farihah F, Faisal M. Learning Media Development Based on "Meme" as Efforts to Prevent Miscellanee Drug Abuse in Class VI of Elementary School. Proceedings of the International Conference on Technology and Vocational Teachers (ICTVT 2017); 28 ${ }^{\text {th }}$ September 2017; Yogyakarta. Atlantis Press; 2017. p. 326-329. 